\title{
Peningkatan Hasil Belajar Siswa Kelas V Mata Pelajaran IPA Menggunakan Model Pembelajaran Kooperatif Tipe NHT (Numbered Head Togethers)
}

\author{
Tri Ardiyanti \\ Progam Studi PGSD, FKIP, Universitas Kristen Satya Wacana Salatiga \\ 292015064@student.uksw.edu
}

\begin{abstract}
ABSTRAK
Penelitian ini bertujuan untuk meningkatkan hasil belajar siswa pada mata pelajaran sains kelas V SD ST.Theresia Marsudirini 77 melalui penerapan model pembelajaran kooperatif tipe NHT (Numbered Head Together). Jenis penelitian yang digunakan adalah penelitian tindakan kelas. Instrumen pengumpulan data yang digunakan adalah lembar observasi hasil belajar pada pra siklus dan hasil belajar dari tes tertulis pada siklus 1. Teknik Analisis data yang digunakan adalah teknik analisis deskriptif komparatif, yaitu membandingkan hasil belajar siswa pada pra siklus dengan siklus 1. Hasil penelitian pada pra-sepeda motor diperoleh data dari 45 siswa ada 13 siswa $(28,89 \%)$ yang tuntas $(\geq 70)$ dan 32 siswa $(71,11 \%)$ belum selesai $(<70)$ dengan nilai rata-rata kelas 54,11 . Sedangkan pada siklus pertama data hasil belajar berubah menjadi 34 siswa $(75,55 \%)$ lengkap $(\geq 70)$ dan 11 siswa $(24,44 \%)$ belum selesai $<70)$ dengan nilai rata-rata kelas 78,79. Berdasarkan hasil analisis uji t keduanya memiliki signifikansi 0,00 atau $<0,05$ (a). Jadi dapat disimpulkan hasil pembelajaran pra siklus dengan siklus 1 adalah signifikan. Berdasarkan hasil observasi dan diskusi penelitian, penerapan model pembelajaran kooperatif tipe NHT pada proses pembelajaran terbukti meningkatkan hasil belajar siswa sebanyak 21 siswa diikuti oleh rata-rata kelas 24,68.
\end{abstract}

Kata kunci: Hasil Belajar, Model Pembelajaran Kooperati, NHT

\section{PENDAHULUAN}

Undang-Undang No.20 Tahun 2003

tentang sistem pendidikan nasional menyatakan bahwa pendidikan merupakan usaha sadar dan terencana untuk mewujudkan suasana belajar dan proses pembelajaran agar peserta didik secara aktif mengembangkan potensi dirinya untuk memiliki kekuatan spiritual, kegamaan, pengendalian diri, kepribadian, kecerdasan, akhlak mulia, serta keterampilan yang diperlukan dirinya, masyarakat, bangsa dan Negara. Pada hakikatnya pendidikan merupakan salah satu kegiatan yang mencakup kegiatan mendidik, mengajar, dan melatih. Dalam serangkaian proses belajar mengajar di sekolah yang dilakukan guru, kegiatan belajar mengajar itu merupakan kegiatan yang paling penting. Keberhasilan pembelajaran di sekolah tergantung dari situasi kegiatan belajar mengajar dan siswa itu sendiri dalam mengikuti proses pembelajaran, dikarenakan saat ini banyak prose pembelajaran yang belum menggunakan variasi dan inovasi baik mengenai strategi, media maupun model pembelajaran. Pembelajaran hanya didominasi oleh guru, sedangkan siswa hanya mendengarkan saja dan masih banyak siswa yang berbicara sendiri pada saat guru menjelaskan tentang materi yang diajarkan. Hal itu dikarenakan pembelajaran kurang menarik bagi siswa. Cara guru mengajar yang hanya satu arah (teacher centered) menyebabkan kurangnya pemahaman siswa terhadap materi yang disampaikan hal itu juga berdampak pada hasil belajar siswa.

Berdasarkan observasi terhadap hasil belajar siswa, yang dilakukan di SD ST Theresia Marsudirini 77 hasil belajar IPA kelas $\mathrm{V}$ pada Tema 3 pembelajaran 2 dengan KD "Menjelaskan organ-organ sistem pencernaan pada manusia serta fungsinya" dari 45 siswa ada $32(71.11 \%)$ siswa yang nilainya belum mencapai Kriteria Ketuntasan Minimal (KKM) yaitu 70. Dan ada 13 siswa (28.89\%) yang dinyatakan tuntas. Dari hasil wawancara yang dilakukan terhadap guru kelas $\mathrm{V}$ hal tersebut dikarenakan guru tidak menginovasikan proses pembelajaran menggunakan strategi dan model yang tepat.

Dari permasalahan tersebut sesuai dengan standar kompetensi yang harus dimiliki guru SD yaitu guru harus menguasai teori belajar dan prinsip-prinsip pembelajaran yang mendidik yang mana juga disebutkan dalam Permendiknas No.16 Tahun 2007 bahwa guru 
harus menerapkan berbagai pendekatan, strategi, metode, dan teknik pembelajaran yang mendidik secara kreatif dalam lima mata pelajaran SD dan yang terakhir guru juga harus menerapkan pendekatan pembelajaran yang tematis. Salah satu dari lima mata pelajaran wajib di SD adalah mata pelajaran IPA. Untuk itu alangkah lebih baik jika seorang guru lebih mempersiapkan sistem pembelajaran dengan membuat Rencana Pelaksanaan Pembelajaran terlebih dahulu agar proses pembelajaran dapat berlangsung secara terstruktur dan saat mengikuti proses pembelajaran siswa tidak bosan serta siswa mampu memahami apa yang menjadi pokok bahasan pada materi IPA sehingga menunjang ketercapaian hasil belajar secara maksimal. Salah satu cara dalam meningkatkan kualitas proses pembelajaran untuk hasil belajar siswa yang maksimal adalah dengan menginovasi proses embelajaran menggunakan model pembelajaran. Salah satu model pembelajaran yang dapat dijadikan alternative dalam proses pembelajaran adalah model kooperatif tipe kepala bernomor (Numbered Head Together). Karena menurut pendapat Huda (2011) (Mawardi, 2016:251-263) mengemukakan diskusi kelompok dengan model pembelajaran tipe NHT dapat memberikan peluang kepada siswa untuk saling bertukar pikiran atau pendapat dan mencari jawaban yang paling tepat secara kolaboratif. Sebagaimana dikemukakan oleh Trianto (2009:82) , bahwa penerapan model pembelajaran kooperatif tipe NHT dalam proses pembelajaran melibatkan banyak anggota kelompok untuk memahami materi yang dipelajari dan mengecek tingkat pemahamn siswa terhadap materi tersebut sehingga dapat men ingkatkan hasil belajar siswa Berdasarkan uraian tersebut, maka peneliti mencoba menerapkan pembelajaran kooperatif dengan model Numbered Head Together untuk meningkatkan hasil belajar siswa kelas V di SD ST Theresia Marsudirini 77 pada pokok bahasan Tema 3 Subtema 1 Pembelajaran 2 mengenai "Sistem Pencernaan Manusia serta fungsinya".

Berdasarkan permasalahan diatas, dalam penelitian ini mengkaji mengenai apakah model pembelajaran kooperatif model Numbered Head Together dapat meningkatkan hasil belajar siswa kelas V mata pelajaran IPA pada Kompetensi Dasar "Sistem pencernaan pada manusia serta fungsinya"?

Tujuan Penelitian ini adalah untuk meningkatkan aktivitas dan hasil belajar mata pelajaran IPA melalui penerapan model pembelajaran kooperatif ftipe NHT (Numbered Heda Together) pada mata pelajaran IPA kelas V siswa SD ST.Marsudirini 77 semester 1 tahun pelajaran 2017/2018.

\section{METODE PENELITIAN}

Penelitian ini menggunakan jenis Penelitian Tindakan Kelas (PTK). Model penelitian ini mengadopsi model PTK dari Kemmis \& Taggart yang membagi procedure penelitian menjadi empat tahap dalam setiap siklusnya yaitu perencanaan (planning), pelaksanaan (acting), observasi (observing) dan refleksi (Reflecting) (Arikunto, 2012:16). Peneitian ini terdiri dari satu siklus dengan satu kali pertemuan. Penelitian ini dilaksanakan pada semester II tapi untuk materi semester I tahun ajaran 2017/2018 tepatnya pada bulan Februari-Maret 2018 di SD ST. Tehresia Marsudrini 77, Kota Salatiga . Subjek dalam penelitian ini adalah siswa kelas V SD ST. Theresia Marsudirni 77 sejumlah 45 siswa. Terdapat dua variabel dalam Penelitian ini antara lain adalah variabel bebas yaitu model pembelajaran NHT (Numbered Head Together) dan variabel terikat yaitu hasil belajar dalam mata pelajaran IPA untuk KD "Sistem Pencernaan Manusia serta Fungsinya). Metode pengumpulan data pada penelitian ini menggunakan alat pengumpulan data berupa; (a) Observasi data nilai hasil belajar Pra-siklus dan wawancara dengan guru kelas;(b) Tes tertulis, digunakan untuk mengukur hasil belajar siswa yang setelah proses pembelajaran dengan menerapkan model pembelajaran kooperatif tipe NHT (Numbered Head Together); (c) Dokumentasi.

Adapun teknik analisis data yang digunakan pada penelitian ini adalah dengan teknik analisis deskriptif kualitatif, dan deskriptif kuantitatif. Deskripsi kualitatif dimaksudkan untuk menggambarkan proses pembelajaran menggunakan model pembelajaran NHT. Sedangkan teknik analisis data dengan cara deskriptif kuantitatif adalah dengan menganalisis hasil belajar dari tes tertulis kemudian ditentukan presentase jumlah siswa yang $</ \geq$ KKM dan rata-rata kelas yang diperoleh siswa setelah penerapan model pembelajaran NHT. Indikator keberhasilan yang dipergunakan adalah hasil belajar siswa siklus 1 harus lebih baik dibandingkan pada prasiklus untuk mata pelajaran IPA terkait KD "Sistem Pencernaan Manusia serta Fungsinya). 


\section{HASIL \& PEMBAHASAN}

Deskripsi Kondisi Awal (Prasiklus)

Berdasarkan Observasi di SD ST.

Theresia Marsudirni 77 pada tanggal 6
Februari 2018, terkait dengan hasil belajar siswa kelas $\mathrm{V}$ untuk mata pelajaran IPA dengan KD “ Menjelaskan sistem pencernaan pada manusia serta fungsinya" dinyatakan dalam tabel berikut :

Tabel 1. Deskripsi Hasil Belajar Pra Siklus

\begin{tabular}{clll}
\hline $\begin{array}{c}\text { Interval } \\
\text { Nilai }\end{array}$ & Kriteria & Frekuensi & Presentase \\
\hline$\geq 70$ & Tuntas & 13 & $\mathbf{2 8 . 8 9 \%}$ \\
\hline$<70$ & Tidak Tuntas & 32 & $\mathbf{7 1 . 1 1 \%}$ \\
\hline
\end{tabular}

Dari tabel 1 diketahui hasil belajar pada kondisi awal (Prasiklus) yang mana proses pembelajaran dilakukan oleh guru kelas $\mathrm{V}$ tanpa menggunakan model pembelajaran kooperatif tipe NHT dalam mata pelajaran IPA terhadap 45 siswa SD ST Theresia Marsudirini 77 diperoleh nilai Terendah 30, Nilai tertinggi 80 , rata-rata mean 54.11 dengan deskripsi ada 13 siswa $(28.89 \%)$ yang tuntas dan 32 siswa $(71.11 \%)$ yang tidak tuntas. Dalam artian hasil belajar pada prasiklus dapat dinyatakan masih 32 (71.11\%) siswa yang nilainya dibawah KKM (70).

\section{Deskripsi siklus 1}

Sesuai dengan metode penelitian, Peneliti melakukan tindakan dengan Tahap Perencanaan (Planning) tahap ini dilakukan dengan mempersiapkan Rancangan Pelaksanaan Pembelajaran (RPP) Tema 3 Subtema 1 pembelajaran 2 tentang mata pelajaran IPA dengan KD "Sistem pencernaan pada manusia serta fungsinya".

Selanjutnya Tahap pelaksanaan (acting) kegiatan belajar mengajar siklus 1 , pada tahap ini adalah proses pelaksanaan pembelajaran, peneliti menginovasi proses pembelajaran menggunakan model pembelajaran kooperatif tipe Numbered Head Together.

Dari tindakan yang dilakukan di Siklus 1 dengan menerapkan model pembelajaran kooperatif tipe NHT sesuai sintak pada mata pelajaran IPA untuk KD "sistem pencernaan dan fungsinya" peneliti mendapatkan hasil belajar sebagai berikut:

Tabel 2. Deskripsi Hasil Belajar Siklus1

\begin{tabular}{|c|c|c|c|}
\hline $\begin{array}{c}\text { Interval } \\
\text { Nilai }\end{array}$ & Kriteria & Frekuensi & Presentase \\
\hline$\geq 70$ & Tuntas & $\mathbf{3 4}$ & $\mathbf{2 4 . 4 5 \%}$ \\
\hline$<70$ & Tidak Tuntas & 11 & $\mathbf{7 5 . 5 5 \%}$ \\
\hline
\end{tabular}

Dari tabel 2 dapat dilihat mengenai hasil belajar siswa kelas $\mathrm{V}$ setelah siklus 1 terlaksana dengan menggunakan model kooperatif tipe NHT dalam proses pembelajaran, peneliti memperoleh data hasil belajar siswa dari tes tertulis yang dilakukan di kahir pembelajaran sebagai berikut, Nilai ratarata siswa 78.77 , dengan deskripsi yang tidak tuntas atau tidak melebihi KKM ada 11 siswa dengan prsentase $24.45 \%$ dan yang tuntas atau melebihi maupun sama dengan KKM yaitu 70 antara lain ada 34 siswa atau $75.55 \%$.

Tabel 3. Hasil Analisis Uji t

One-Sample Statistics

\begin{tabular}{|l|r|r|r|c|}
\hline & $\mathrm{N}$ & Mean & Std. Deviation & $\begin{array}{c}\text { Std. Error } \\
\text { Mean }\end{array}$ \\
\hline 2 & 90 & 66.44 & 19.098 & 2.013 \\
\hline
\end{tabular}


One-Sample Test

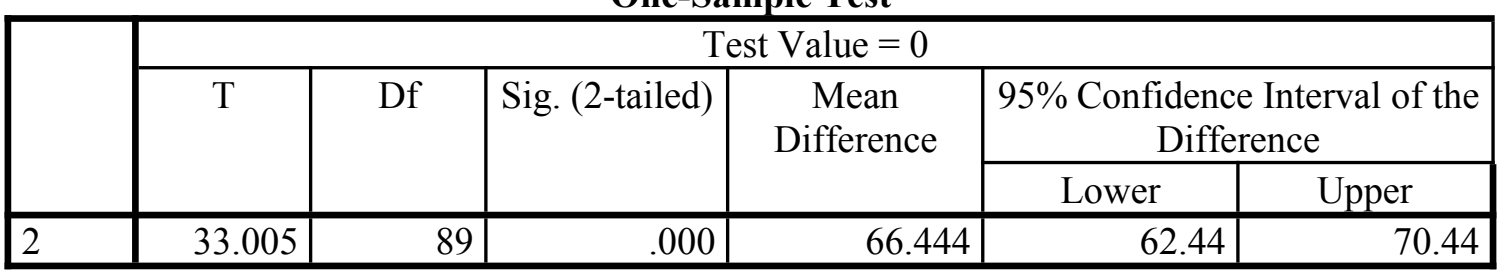

Dari tabel 3 terlihat analisis data menunjukan bahwa hasil belajar dari prasiklus (tanpa model pembelajaran NHT) dengan siklus 1 (menggunakan model pembelajaranNHT) adalah signifikan karena signifikansi menunjukan nilai 0,00 dimana nilai ini kurang dari taraf siginifikan yaitu $5 \%$.

\section{Observasi Pembelajaran}

Dari hasil observasi pelaksanaan pembelajaran ada perbandingan hasil belajar siswa sebelum tindakan dan sesudah tindakan yang diperoleh data antara lain adalah pada grafik berikut:

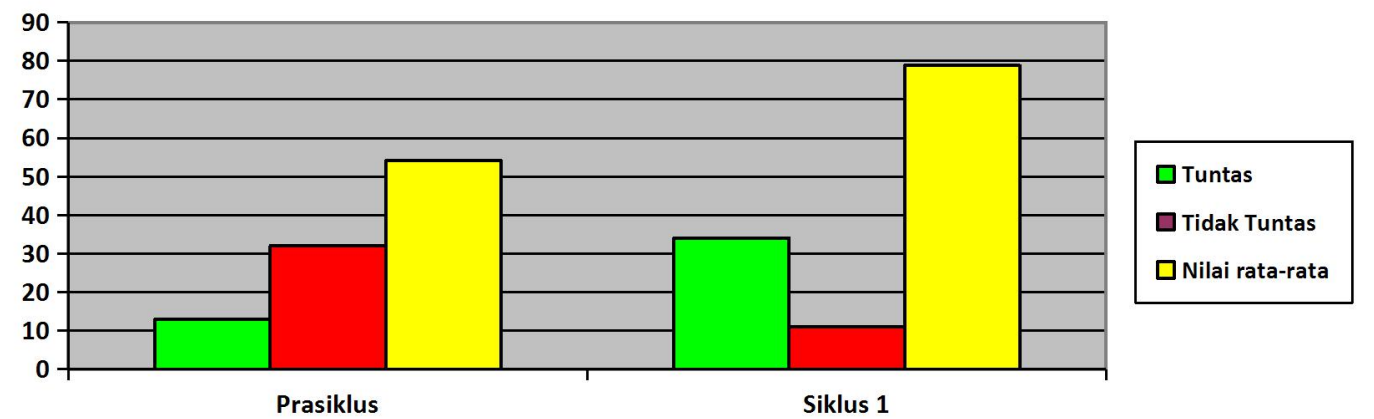

Gambar 1. Grafik Komparasi Hasil Belajar Prasiklus dengan Siklus 1

Dari grafik 1 diatas dapat dilihat perbandingan jumlah siswa yang tuntas, tidak tuntas, dan nilai rata-rata pada prasiklus dengan siklus 1. Pada prasiklus grafik menunjukan jumlah siswa yang tuntas ada 13 siswa, lalu siswa yang tidak tuntas ada 32 siswa dan nilai rata-rata kelas adalah 54.11. Sedangkan pada siklus 1 grafik menunjukan ada 34 siswa yang tuntas diikuti 11 siswa yang tidak tuntas dan didukung nilai rata-rata kelas dengan presentase 78.79 .

\section{Refleksi}

Refleksi berdasarkan pelaksanaan pembelajaran pada siklus 1 antara lain, pembelajaran dengan model pembelajaran kooperatif tipe NHT dilakukan sesuai sintak, penerapan model pembelajaran yang sesuai sintak memberi ruang untuk mencapai hasil belajar yang maksimal.

\section{Pembahasan}

Penelitian ini dilakukan di SD ST.Theresia Marsudirini 77 kelas V untuk mapel IPA dengan KD "Sistem penernaan manusia serta fungsinya". Pada Prasiklus dengan menerapkan model pembelajaran kooperatif tipe NHT sesuai dengan sintaknya. seperti yangada pada bab 1 yang menjadi rumusan masalah dalam penelitian ini adalah apakah ada perebedaan hasil belajar Prasiklus (tanpa menggunakan model pembelajaran NHT) dibandingkan dengan hasil belajar siklus 1 (dengan menggunakan model pembelajaran NHT).

Berdasarkan tabel 1 mengenai deksripsi hasil belajar siswa pada prasiklus, yang mana proses pembelajaran dilakukan tanpa menggunakan model pembelajaran kooperatif tipe NHT menunjukan hasil dari 45 siswa ada 13 siswa $(28.89 \%)$ yang tuntas $(\geq 70)$ dan ada 32 siswa $(71.11 \%)$ yang tidak tuntas dengan nilai $(<70)$ disertai nilai rata-rata sejumlah 54.11. Sedangkan dari tabel 2 yaitu deskripsi hasil belajar siswa pada siklus 1 , dimana proses pembelajaran menerapkan model pembelajaran kooperatif tipe NHT diperoleh hasil bahwal dari 45 siswa ada 34 siswa $(75.55 \%)$ dinyatakan tuntas $(\geq 70)$ dan 11 siswa $(24.45 \%)$ tidak tuntas $(<70)$ diiikuti nilai rata-rata sejumlah 78.79 . Hal ini menunjukan bahwa pada penelitian ini proses pembelajaran dengan menggunakan model pembelajaran kooperatif tipe NHT lebih efektif meningkatkan hasil belajar IPA siswa kelas V SD ST.Theresia marsudirini 77 dibandingkan dengan model pembelajaran konvensional, dengan deskripsi setelah siklus 1 dilakukan jumlah siswa yang tuntas meningkat sebanyak 
21 siswa (46.66\%) dari 13 siswa yangtuntas menjadi 34 siswa diikuti dengan peningkatan nilai rata-rata dimana pada saat pra siklus sejumlah 54.11 menjadi 78.79 setelah siklus 1 .

Dari hasil analisis Uji t dan komparasi prasiklus dengan siklus 1 pada tabel 3 dan grfik 1 menunjukan bahwa Nilai $\mathrm{t}$ hitung 33.005 dengan signifikansi $0,00<0,05$ maka Ho ditolak dan Ha diterima karena nilai ratarata prasiklus sejumlah 54.11 menjadi 78.79 pada siklus 1 dan komparasi ini dinyatakan signifikan. Model pembelajaran koopertif tipe NHT ini memberikan dampak terhadap peningkatan hasil belajar siswa. Hal ini sejalan dengan pendapat Trianto (2009:82) yang ditulis peneliti pada pada pendahuluan yang menyebutkan bahwa proses pembelajaran menggunakan model pembelajaran kooperatif tipe NHT melibatkan banyak anggota kelompok untuk memahami materi yang dipelajari dan mengecek tingkat pemahaman siswa sehingga dapat meningkatkan hasil belajar siswa.

Penelitian ini sejalan dengan penelitian yang dilakukan oleh Mawardi (Hanifah dan Mawardi,2016:251.263) dalam penelitian yang berjudul Penerapan Model Pembelajaran kooperatif Tipe NHT dan STAD ditinjau dari Hasil Belajar Siswa. Yang menyimpulkan bahwa ada signifikansi antara penerapan model pembelajaran NHT dan STAD yang juga didukung dengan nilai rata-rata hasil postest pembelajaran NHT sebesar 81 dan STAD sebesar 74. Dalam pembahasan penelitian ini menyatakan bahwa model pembelejaran NHT lebih efektif meningkatkan hasil belajar siswa. Selain itu penelitian ini juga mendukung penelitian Yeni (2016:263-267) dengan judul "Penggunaan Metode Numbered Head Together (NHT) dalam Mata Pelajaran Matematika" yang menyimpulkan bahwa hasil belajar matematikan menggunakan metode pembelajaran NHT yang diterapkan di kelas IV SDN pasanggrahan 1 Kecamatan MajaMajalengka lebih baik dari pada hasil belajar matematika yang menggunakan pembelajaran konvensional.

Tidak hanya Mawardi dan Yeni penelitian ini juga mendukung penelitian dari Mulyana, Hanifah dan Kurnia (2016) yang mana dari hasil uji komparasinya bahwa hasil observasi data awal diperoleh dari 30 siswa siswa yang tuntas ada 8 siswa dan yang belum tuntas 22 siswa, lalu dengan menerapkan model pembelajaran koperatif tipe NHT dalam sikuls I, ada 12 siswa yang tuntas dan 17 siswa tidak tuntas karena belum mencapai target
$86,20 \%$, dilakukan siklus II dengan menerapkan model yang sama danmeningkat menjadi 20 siswa yang tuntas dan 9 siswa yang belum tuntas. Karena masih belum mencapai targer Mulyana dkk (2016) melakukan siklus III dan mendapatkan hasil 26 siswa yang tuntas dan 4 siswa tidak tuntas. Dapat dilihat dari hasil penelitian Mulyana dkk (2016) setiap siklus dengan penerapan model pembelajaran kooperatif tipe NHT mengalami peningkatan. Jadi dapat disimpulkan dari berbagai penelitian diatas mengenai peningkatan hasil belajar siswa dengan penerapan model pembelajaran kooperatif tipe NHT mampu meningkatkan hasil belajar siswa.

Keberhasilan Penelitian ini karena kelebihan dari Model NHT yaitu sebagaimana dikemukakan oleh Huda (2011:139) bahwa model NHT memudahkan siswa dalam membagi tugas anggota kelompok, memudahkan siswa melaksanakan tanggungjawab secara individu sebagai anggota kelompok, memudahkan siswa dalam mencari jawaban yang tepat, selain itu dapat dierapkan untuk semua mata pelajaran dan tingkatan kelas.

Langkah pembelajaran dengan Model kooperatif tipe NHT yaitu langkah yang pertama, guru membagi siswa dalam kelompok heterogen, dan setiap siswa dalam kelompok mendapat nomer 1,2,3,4 sampai 5 . Lalu sintak kedua, pendidik memberikan tugas kepada masing-masing kelompok (untuk setiap kelompok mendapatkan nilai yang sama, tapi untuk tiap siswa tidak sama, misalkan siswa nomor 1 menjawab soal nomor 1 dan seterusnya sampaidenganno 5, tapi untuk setiap siswa dengan nomor yang sama mendapat saoal yang sama) setelah itu sintak yang ketiga, guru meminta kelompok mendiskusikan jawaban yang benar dan memastikan tiap anggota kelompok dapat mengerjakannya. Selanjutnya sintak yang keempat, guru memanggil salah satu nomor siswa untuk menjawab/melaporkan hasil kerjasama mereka kedepan. Untuk sintak yang kelima, jawaban siswa diberi tanggapan dari teman lain, kemudian guru menunjuk nomor yang lain (terjadi diskusi kelas). Lalu sintak yang keenam yaitu, siswa diberi soal individu untuk mengukur skor perkembangan tiap siswa, lalu setelah siswa selesai mengerjakan guru bersama siswa menyimpulkan materi pembelajaran dan mengumumkan hasil tugas individu (melewati koreksi bersama) dan meberikan reward kepada nilai tertinggi. 


\section{KESIMPULAN \& SARAN}

Hasil belajar prasiklus dengan siklus 1 pada kelas V untuk mata pelajaran IPA di SD ST.Theresia Marsudirini 77 dinyatakan signifikan. Signifikansi juga didukung oleh perbedaan nilai rata-rata prasiklus yaitu 54.11 dan pada siklus 1 78.79. Dan dari hasil penelitian berbagai sumber yang tertera pada pembahasan dapat dinyatakan jika model pembelajaran kooperatif tipe NHT lebih efektif digunakan untuk proses pembelajaran berbagai jenjang dan untuk berbagai mapel serta efektif mampu meningkatkan hasil belajar siswa.

\section{Saran}

Berdasarkan hasil penelitian yang telah dilakukan diketahui bahwa penerapan model pembelajaran kooperatif tipe NHT (Numbered Head together) ini mampu meningkatkan hasil belajar siswa. Oleh karena itu peneliti memberikan saran kepada guru agar lebih dapat mengembangkan lagi standar kompetensi yang harus dimiliki guru dengan salah satunya menggunakan model pembelajaran dalam proses belajar mengajar sehingga siswa tidak bosan dan pemahaman siswa terhadap materi juga meningkat. Dan sebagai alternative penggunaan model guru dapat menggunakan model kooperatif tipe NHT.

\section{DAFTAR PUSTAKA}

Arikunto, Suharsimi. 2012. Penelitian

Tindakan Kelas. Jakarta: Bumi Aksara

Darmadi. 2017. Pengembangan Model Metode

Pembelajaran dalam Dinamika

Belajar Siswa. Yogyakarta: CV. Budi Utama

Desi Putrianasari, D., \& Wasitohadi, W. (2015). Pengaruh Penerapan Pendekatan Contectual Teaching and Learning (CTL) terhadap Hasil Belajar Matematika Ditinjau dari Motivasi Siswa Kelas 5 SD Negeri Cukil 01 Kecamatan TengaranKabupaten. Scholaria: Jurnal Pendidikan Dan Kebudayaan, 5(1), 57-77.

https://doi.org/https://doi.org/10.24246 /j.scholaria.2015.v5.i1.p57-77

Huda, M. 2011. Cooperatif Learning Metode, Teknik, Struktur dan Model Penerapan. Yogyakarta:Pustaka Pelajar

Komalasari, Kokom. 2010. Pembelajaran kontektual (Konsep dan Aplikasi).Bandung: Refika Aditama
Kusumawati, H., \& Mawardi, M. (2016). Perbedaan Penerapan Model Pembelajaran Kooperatif Tipe NHT dan STAD Ditinjau dari Hasil Belajar Siswa. Scholaria: Jurnal Pendidikan Dan Kebudayaan, 6(3), 251-263. https://doi.org/https://doi.org/10.24246 j.scholaria.2016.v6.i3.p251-263

Mawardi.2017. Merancang Model dan Media Pembelajaran. Salatiga: Journal. FKIP PGSD UKSW. Vol-8, No. 1: 26-40

Mawardi, M., \& Mariati, M. (2016). Komparasi Model Pembelajaran Discovery Learning dan Problem Solving Ditinjau Dari Hasil Belajar IPA Pada Siswa Kelas 3 SD di Gugus Diponegoro - Tengaran.. Scholaria: Jurnal Pendidikan Dan Kebudayaan, 6(1), 127-142. https://doi.org/https://doi.org/10.24246 /i.scholaria.2016.v6.i1.p127-142

Mediatati, N. (2012). Penerapan Model Pembelajaran Kooperatif Tipe Learning Togeteher Untuk Meningkatkan Keaktifan dan Hasil Belajar Siswa Kelas XI B Pada Mata Pelajaran PKN di SMK PGRI II Salatiga. Satya Widya, 28(1), 39-54. https://doi.org/https://doi.org/10.24246 j.sw.2012.v28.i1.p39-54

Mulyana, Mutia Agisni, Hanifah Nurdinah, \& Jayadinata, Asep Kurnia. 2016. Penerapan Model Kooperatif Tipe Numbered Head Together (NHT) Untuk Meningkatkan Hasil Belajar Siswa Pad Materi Kenampakan Alam dan Sosial , Vol-1(1), Jurnal Pena Ilmiah.

http://ejournal.upi.edu/index.php/penai $\underline{\operatorname{lmiah} / \text { article/viewFile/3039/pdf }}$

Peraturan Menteri Pendidikan Nasional Republik Indonesia..2007. Permendiknas No 16 Tahun 2007. Standar Kualifikasi akademik dan kompetensi guru.

Suprihatiningrum, Jamil. 2013. Strategi Pembelajaran Teori dan Alikasi. Yogyakarta: AR-RUZZ MEDIA

Tampubolon, Saur. 2014. Penelitian Tondakan Kelas (Sebagai Pengembangan Profesi Pendidik dan Keilmuan). Jakarta: Erlangga

Trianto, 2009. Mendesain Model Pmbelejaran Inovatif-Progresif. Jakarta: Kencana Prenada Group

Undang-Undang No. 20. 2003. Tentang Sistem Pendidikan Nasional. Pasal 37 
Widayanti, E., \& Slameto, S. (2016). Pengaruh Penerapan Metode Teams Games Tournament Berbantuan Dadu Terhadap Hasil Belajar IPA. Scholaria: Jurnal Pendidikan Dan Kebudayaan, 6(3),182-195. https://doi.org/https://doi.org/10.24246 j.scholaria.2016.v6.i3.p182-195 publish: 2016-09-28

Widiantono, N. (2017). Penerapan Model Pembelajaran Interaktif Untuk Meningkatkan Aktivitas dan Hasil Belajar IPA Siswa Kelas 5. Scholaria: Jurnal Pendidikan Dan Kebudayaan, 7(3), 199-213. https://doi.org/https://doi.org/10.24246 j. scholaria. 2017. v7. i3.p199-213

Yeni, Rika firma. 2016. Penggunaan Metode Numbered Head Together (NHT) dalam Pembelajaran Matematika. http://jurnal.untirta.ac.id/index.php/JP PM/article/view/1006/804 JPPM, Jurnal Penelitian dan Pembelajaran Matematika. Journal is published by Jurusan Pendidikan Matematika FKIP Universitas Sultan Ageng Tirtayasa (print) and Jurnal Untirta (eprint). JPPM, Vol-9(2), 263267 